\title{
End-of-life care across Southern Europe: A critical review of cultural similarities and differences between Italy, Spain and Portugal
}

\author{
Arantza Meñaca $^{\mathrm{a}, *}$, Natalie Evans $^{\mathrm{a}}$, Erin V.W. Andrew ${ }^{\mathrm{a}}$, Franco Toscani $^{\mathrm{b}}$, Silvia Finetti ${ }^{\mathrm{b}}$, \\ Xavier Gómez-Batiste ${ }^{\mathrm{c}}$, Irene J. Higginson ${ }^{\mathrm{d}}$, Richard Harding ${ }^{\mathrm{d}}$, Robert Pool ${ }^{\mathrm{a}, \mathrm{e}}$, \\ Marjolein Gysels ${ }^{\mathrm{a}}$

\footnotetext{
${ }^{a}$ Barcelona Centre for International Health Research (CRESIB - Hospital Clínic - Universitat de Barcelona), Rosselló 132, S.A. 1, Barcelona 08036, Spain ${ }^{\mathrm{b}}$ Fondazione Lino Maestroni-ONLUS, Cremona, Italy

${ }^{\mathrm{c}}$ The Qualy Ovservatory/WHO Collaborating Center for Palliative Care Programmes, Institut Català d'Oncologia, l'Hospitalet, Barcelona, Spain

${ }^{\mathrm{d}}$ King's College London, Cicely Saunders Institute, Department of Palliative Care, Policy \& Rehabilitation, London, UK

${ }^{\mathrm{e}}$ Centre for Social Sciences and Global Health, University of Amsterdam, Amsterdam, The Netherlands
}

Accepted 9 June 2011

\section{Contents}

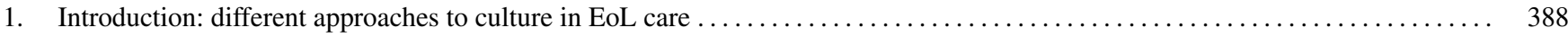

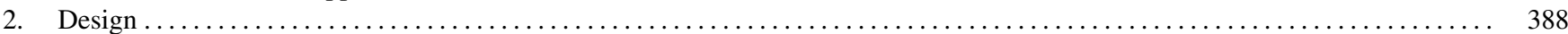

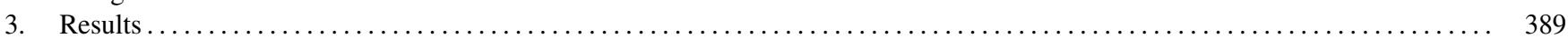

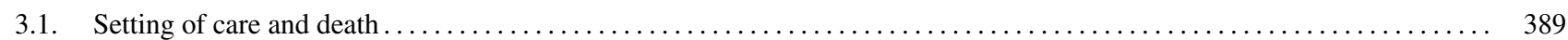

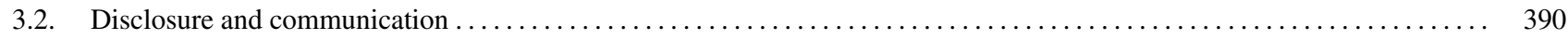

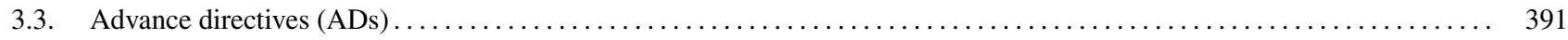

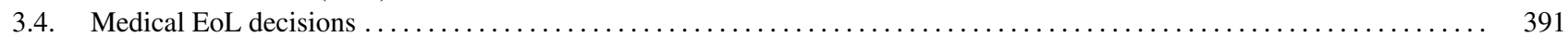

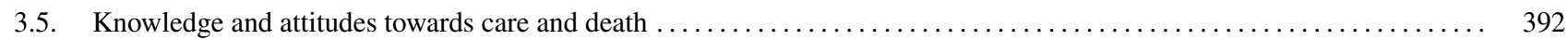

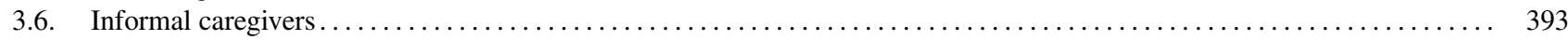

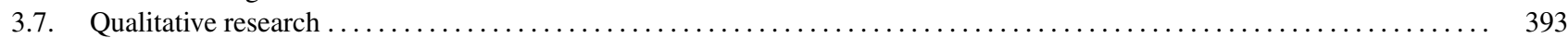

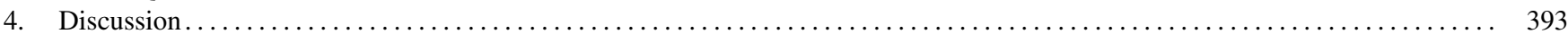

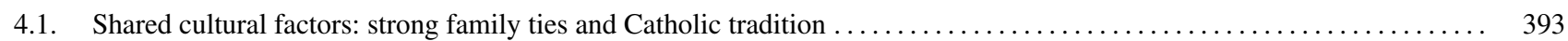

4.2. Cultural analysis and improvement of EoL care in Italy, Spain and Portugal . . . . . . . . . . . . . . . . . . . 394

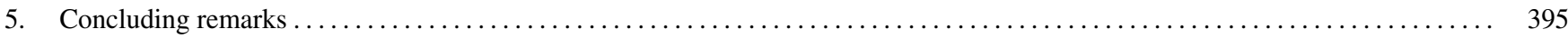

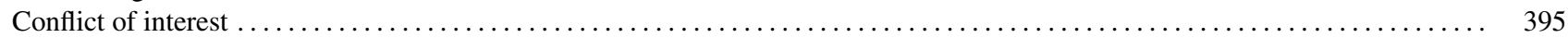

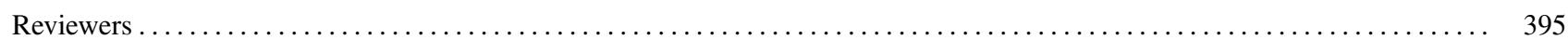

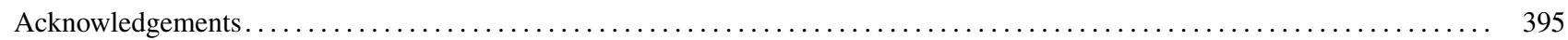

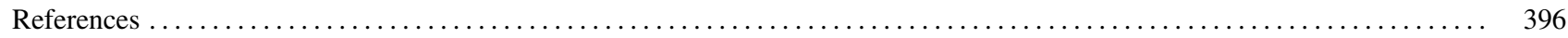

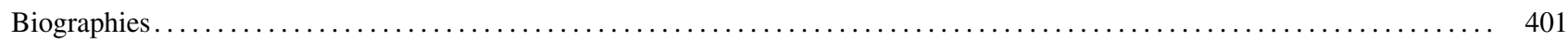

\begin{abstract}
Evidence from a range of sources demonstrates that end-of-life (EoL) care practices and preferences vary across countries; culture is consistently one of the main explanations given for this. In order to understand how cultural factors are used to explain similarities and differences in EoL care between Spain, Italy and Portugal, database and hand searches were performed and cross-cutting core themes identified. Similarities included higher proportions of people who wished to die at home than actually died at home, a persistent trend for partial disclosure in Italy and Spain, low use of advance directives, and low incidence of all medical EoL decisions (with the exception of
\end{abstract}

Abbreviations: ADs, advance directives; DNRs, do-not-resuscitate orders; EoL, end-of-life; ICUs, intensive care units.

* Corresponding author. Tel.: +34 932271845 ; fax: +34 932271844.

E-mail addresses: arantza.menaca@cresib.cat, arantzamenaca@gmail.com (A. Meñaca). 
terminal sedation) compared to northern European countries. The role of religion and the importance of family ties were the two main cultural factors used to explain the similarities. Further research is needed in order to interpret the important differences that were also found.

(C) 2011 Elsevier Ireland Ltd. All rights reserved.

Keywords: Palliative care; End of life; Family; Religion; Southern Europe; Culture

\section{Introduction: different approaches to culture in EoL care}

There is growing interest to integrate the cultural dimension in EoL care [1-3]. However, culture is a broad, multilayered concept [4-6] and the approach taken to understanding culture influences its potential contribution to improving EoL care. There are at least three different perspectives on the relationship between culture and medicine. These three perspectives can also be distinguished in the context of EoL care.

The most common approach links culture to the ways different groups of lay people understand and face health, illness and death: it is considered important to understand the culture of specific patient groups in order to improve their access, and adherence to medical services and treatments. This was the first approach to be used in medical anthropology and, nowadays, in western countries, it is mainly used to understand the behaviour of immigrant, minority and ethnic groups and is associated with clinical notions of 'cultural competence', 'cultural sensitivity' or 'cultural awareness' [7-9]. Nevertheless, it can also be associated with patients' other characteristics: illness related practices may also differ depending on age, gender, urban or rural origin, etc.

A second perspective, or group of perspectives, recognizes medicine itself as a cultural system with a specific understanding of disease, human body, and cure [4]. It also acknowledges the differences between specialties within medicine in the way they understand disease, treatment and care [10]. This is the perspective of those who explain palliative care as a 'new culture' within medicine [11], whose aim is to give total care to patients approaching EoL, and thus, differs from the main curative, death-denying approach of some other specialties.

Finally, a third perspective explores the geographic, social and cultural contexts of both patients and medical systems [12]. This approach is helpful in understanding why supposedly neutral, scientific and medical practices vary from place to place. This is the approach to culture applied in this article.

Evidence from a variety of sources suggests that many EoL care related practices, such as pain management [13], medical EoL decisions [14-16], and disclosure of life threatening diseases $[17,18]$, vary across regions of the world, countries, or regions within countries. The influence of culture is consistently given as one of the main explanations for this variability [13-18]. In these comparisons, Italy, Spain, and Portugal are usually grouped together as part of 'Southern Europe' $[19,20]$, the 'Mediterranean area' [21,22], or as representing 'Latin' [23], or 'Catholic' [14,24] culture. Other countries, such as France and Greece, share some, but not all, of these characteristics. When grouped together, they are frequently contrasted with other sets of countries, such as those defined as 'Northern European', 'Anglo-Saxon' or 'Protestant'.

This article aims to understand how, in the literature, cultural factors are used to explain the similarities and differences between EoL care practices and preferences in Spain, Italy and Portugal. First, the preferences and practices in several EoL care domains in Italy, Spain and Portugal are synthesised, with a focus on the similarities and differences found between the three countries. Later, the explanatory potential and limits of the cultural factors, as they are used in the literature, are discussed. Throughout, special attention is given to qualitative research as a means to understand the role of culture in EoL care in different countries.

\section{Design}

This critical review of the literature was undertaken as part of the EU (FP7) supported PRISMA programme which aims to inform best practice and harmonise research in EoL care for cancer patients across Europe [25]. PRISMA incorporated a work package on the influence of culture on EoL care in different European countries.

Country-specific searches were performed in eight international and four Spanish databases (Table 1), using a set of search terms for the country, EoL care, and cultural factors. The search terms for cultural factors were chosen with the aim of retrieving articles concerning EoL care where cultural and social factors were sufficiently relevant to be referred to in the title, abstract, topic or key words, and articles which used qualitative, and particularly anthropological techniques (Table 1).

Reference searches were also undertaken using articles retrieved from database searches. In addition, key Spanish and Portuguese palliative care and cancer web pages, the Spanish medical anthropology bibliography compiled by Perdiguero and Comelles [26], and the abstracts from a number of Spanish and European medical anthropology conferences were also consulted (Table 1). Furthermore, a number of articles were recommended by experts participating in the PRISMA project's network of experts in cultural issues in EoL that was set up in parallel to the literature reviews. Articles in English, Spanish, Portuguese and Italian were included.

In the final selection of articles, original studies that focused on 'culture', operationalised as the perceptions, opinions, understandings, knowledge, preferences, attitudes, practices and behaviours of the different actors involved in 
Table 1

Search strategy.

Electronic database searched (last update 14th December 2010)

ISI Web of Knowledge (all databases)

OVID (AMED; MEDLINE; PsycINFO; and EMBASE)

Cancerlit

ASSIA

CINAHL

IME (Spanish Medical Sciences database)

ISOC (Spanish Social Sciences database)

CUIDEN (Spanish Nursing database)

ENFISPO (Spanish Nursing database)

Search terms

(Spain OR Spanish*)/(Italy OR Italian*)/(Portugal OR Portug*)

AND (palliative OR terminal OR "end of life" OR end-of-life OR death OR dying OR "continu* care" OR "advance directive*" OR hospice* OR "supportive care")

AND (ethnic* OR migrant* OR minorit* OR diversity OR cultur* OR intercultural OR cross-cultural OR transcultural OR qualitative OR ethnography OR anthropology OR interview* OR "focus group*”)

Hand searches

Reference lists of retrieved articles

Spanish medical anthropology bibliography (available in Perdiguero and Comelles [26])

Spanish National Conferences of Anthropology;

The REDAM Conferences;

The Medical Anthropology at Home Conferences.

Spanish Society of Palliative Care website (SECPAL)

Basque Society of Palliative Care website (SOVPAL)

Spanish Association Against Cancer website (AECC)

Associação Portuguesa de Cuidados Paliativos website

História dos Cuidados Paliativos em Portugal website

ONCO.news (Associação de Enfermagem Oncológica Portuguesa AEOP)

'Expert Network' recommendations

EoL care, were included. Reviews, overviews, theoretical proposals, reflections and opinion pieces with a cultural or societal perspective on EoL care were also included. For the purpose of this article, a cross-cultural comparison between the three countries, studies that looked at the cultural preferences and practices of specific patient groups such as migrants or ethnic minorities were excluded (14). Articles that only focused on the cultural singularities of palliative care as compared to other specialties and in the context of Western societies relation with death were also excluded (20).

Cross-cutting themes and their subcategories were identified during data extraction and used to code the articles' content. The results for each country were systematized in data extraction tables, and integrated with qualitative metasynthesis: the data obtained for the three countries were compared to highlight similarities and differences, and the cultural explanations given for them [27].

\section{Results}

One hundred and twenty-one documents for Italy, 32 for Portugal and 130 for Spain were available for full text assessment. The majority of these articles were original studies. The rest were mainly overviews, opinion pieces or critiques. Only four reviews were identified and two of them were related to disclosure (Fig. 1). Nineteen articles included data from two or three of the countries.

The main topics that arose from the search process as relevant for a cultural analysis were: setting of care and death, communication and disclosure, medical EoL decisions, knowledge and attitudes towards care and death, and informal caregivers.

\subsection{Setting of care and death}

In 2005, the number of healthcare centres offering palliative care services available per million inhabitants was six in Spain, four in Italy and one in Portugal, far fewer than in Belgium and Sweden (12), the UK (15), or Iceland (20) [28]. Both in Italy and Spain, home care teams constituted the main palliative care resource available. The second main palliative care resource varied across the countries. In Spain, inpatient units were most common. In Italy, hospice care had been increasingly common: the number of hospices rose from four in 1996 [29] to 90 in 2005 [28] mainly due to the influence, since 1999, of new national and regional policies on palliative care [30]. In Portugal, development of palliative care services and research began later than in Spain and Italy and palliative care services are less widespread. In all three countries, important regional inequalities in the distribution of EoL services and were found [28,31,32].

In each country, studies of the general population revealed low expectations of palliative care service provision. Only $36 \%$ of respondents to an Italian survey in 2000 knew the meaning of the term 'palliative care' and $85 \%$ did not know of any palliative care centre [33]. A study from Portugal in 2008, revealed greater knowledge of the meaning of palliative care; although half the interviewees were familiar with the term, they believed that palliative care was not implemented in the majority of public hospitals, and that bigger development of palliative care was needed [34]. Finally, in Spain, in 2009, less than one third of the population considered that the health system had sufficient resources to care for terminal patients [35].

The importance of home care in these countries could be expected to influence the place people die. Among the three countries, countrywide statistical data on place of death could only be found for Portugal: in 2005 almost one-third of all deaths occurred at home [36]. In Spain, the identified studies presented a range of percentages of home deaths: from $22 \%$ for elderly people who died in Catalonia in 1998 to $50 \%$ for terminal cancer patients in Asturias in 1995 [37-43]. Finally in Italy, the proportion of home deaths among cancer patients ranged from $36 \%$ for all 2002 cancer death certificates in Tuscany, Emilia-Romagna and Milan [44] to 58\% in a mortality follow-up survey with nationally representative data from 2002 and 2003 [45]. Italian percentages for non-cancer home deaths were lower $[15,44,46]$. Place of death was found to be related to age, gender, socioeconomic status, cause of death, and region within the country, rural or urban environment, and the resources available in the area $[38,40,43-46]$. 


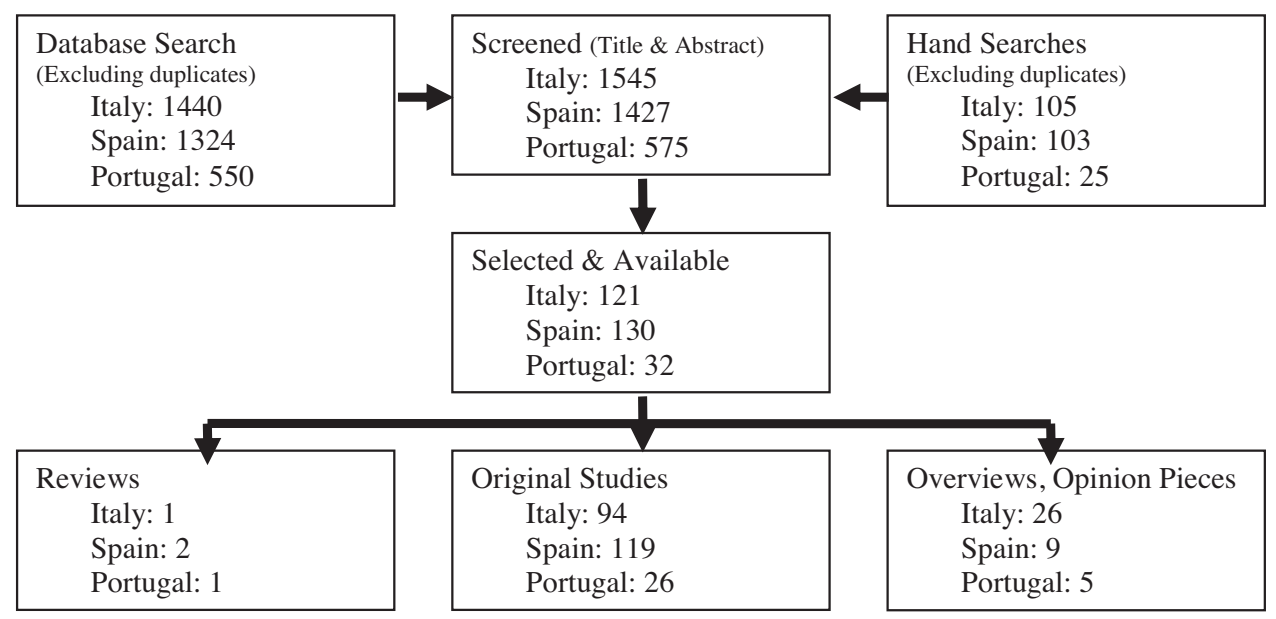

Fig. 1. Search flow.

Within Italy, region was found to be a determining factor in place of death: in the south, where health services are less widely available, the percentage of home deaths increased to $94 \%$ for cancer patients $[45,47]$.

Good practices in EoL care include people dying in their place of preference. However, both in Spain and Italy, the proportion of healthy people who would like to die at home was found to be higher than the proportion who actually died at home [35,43,46,48-52]. Only one recent Spanish survey revealed higher preferences for specific care settings for terminal patients or hospitals $(50 \%)$ than for home death (45\%) [35]. Patients and caregivers reported higher preferences for home care, reaching $94 \%$ in Italy $[43,45,53]$. Spain is the only country where doctors' opinions regarding place of death have been frequently sought and the included studies revealed a greater consensus among healthcare professionals than among the general public that the home is the ideal place of death [54-57]. Moreover, in three of the reviewed articles, the authors (health professionals) assumed that the patient's home is the 'ideal' or 'correct' place for EoL care $[37,40,41]$.

\subsection{Disclosure and communication}

Among the reviewed articles, disclosure of information regarding diagnosis, prognosis and treatments was found to be the most frequently discussed topic (27 articles from Spain, 46 articles from Italy and 8 articles from Portugal). International comparisons describing southern European countries as examples of partial and non-disclosure $[17,18,58]$ were the starting point of this interest, and reviews on the subject have been published both for Spain, in 1998 [59], and Italy, in 2004 [60].

The complexity and detail of measurement of disclosure and awareness has increased since the first studies in the late eighties. It is therefore important to differentiate between: the information given to the patient, his/her awareness of the situation, and the preferences of the general population, patients, relatives and/or doctors; communication about diag- nosis, prognosis or treatments; and, methods, subjects and tools used to collect the information.

Spanish and Italian awareness studies published between 1994 and 2009 suggested that the partial disclosure trend persisted throughout these years. In Italy, direct assessment studies of patients' full awareness of cancer diagnosis and prognosis showed that it remained at under 45\% [61-69]. Meanwhile, the relatives interviewed in the cancer mortality follow-up survey from 2000 considered it to be higher: around $63 \%$ [70]. In Spain, full awareness of diagnosis ranged from $19 \%$ to $64 \%$, depending on the disease, questions and design of the study. There was not however a clear trend over time [37,51,53,71-74]. In both countries, awareness was found to be higher than the information given $[59,63,70,71]$, and more information about diagnosis was given than about prognosis $[61,63,70,72]$. Significant regional differences were also described in Italy [70].

Other findings, however, suggested that preferences may be evolving towards open disclosure. For example, the percentage of the Spanish population that would like to know their diagnosis and prognosis in case of terminal illness has increased over recent decades [35,49-51,55,75], and the percentage of Italian doctors who considered full disclosure ideal has also increased [76-79]. Intermediate positions were also found; for instance, the majority of Spanish doctors stated that they would inform the patient only in certain circumstances or if requested by the patient [54-57,75,80-83]. Two main obstacles to the communication of bad news were identified in Spanish health professionals' discourse on disclosure: acceptance of the wishes of the family, hence tolerating the 'conspiracy of silence imposed by the relatives', and feeling uncomfortable and unprepared to give bad news. Doctors in hospitals were found to be more comfortable communicating bad news than doctors in primary healthcare settings and nurses, who often consider the communication of bad news to be doctors' responsibility [84].

In Portugal, only two studies, both conducted in Porto, in 1999 and 2005, which addressed awareness were found. Both 
studies described greater patients awareness (60-69\%) and desire for information than in Spain or Italy $[85,86]$.

Different interpretations of the trend for partial or nondisclosure in Italy and Spain were found in the literature. In bioethics, disclosure and the doctor/patient relationship was framed within the theoretical debate concerning the tension between the bioethical principles of 'autonomy' and 'beneficence' $[18,60]$. Some authors considered that an excessive preoccupation with individual autonomy does not capture the essence of the patient-doctor relationship: asymmetry of power and patient vulnerability [87]. Yet, the emphasis on beneficence could leave patients unprotected from paternalistic intrusions by family members and doctors $[58,88]$. In order to find the balance between autonomy and beneficence in practice, bioethicists pointed out the variability of personal situations and cultural context, and the need to act with cultural sensitivity/competence $[89,90]$.

Other bioethical and psychological studies focused on the process of communication and the meanings of 'truth'. Communication was described as a complex, dynamic process that accounted for differences in the awareness and wellbeing of the patient [62,91-97]. Truth was understood as a relational state $[87,98,99]$, and in Catholic countries, communication was considered to be influenced by the Catholic tradition of gradual truth giving [24]. Overall, different communication strategies, shared between doctors and patients, were described. In countries such as the US it was considered that patients needed to be explicit if they did not wish to know this information [100], whereas in others like Spain, patients would not be given all the information if they did not ask for it explicitly [101].

Finally, non-disclosure in Italy was also understood as a way to maintain hope and continuity of social life [24,102-105]. An anthropological study described life in Tuscany as an unpredictable flow of events shared by all members of society. Amidst this flow of events, the most vulnerable were protected and cared for. Avoiding the certainty inherent in doctors' diagnosis/prognosis was considered to avert the separation of the individual from social life and, therefore, an anticipated social death [104,105].

\subsection{Advance directives (ADs)}

Important legal differences were found regarding ADs between Spain, Italy and Portugal. In Italy ADs are not legally recognised. Recently a non-binding law has been proposed and there is intense debate, influenced by public opinion, concerning a number of high-profile cases [106-109]. In Portugal, the Council of Ethics has produced some guidance documents. In some instances the documents contradict one another: although ADs are considered binding in the case of a persistent vegetative state, ADs regarding blood transfusions are not binding [110]. In contrast with Italy and Portugal, in Spain, the legal and administrative development of ADs is one of the most advanced in Europe [111].
Among the three countries there were also differences in professionals' attitudes towards ADs. In 2002, most Spanish doctors considered the implementation of ADs policies in Spain to be a positive development [112], whereas Italian oncologists and doctors had little knowledge of such documents, and at least half the oncologists and doctors were not inclined to respect patients' previous decisions [113-115].

The general public's knowledge and use of ADs was reported to be limited in both Spain and Italy (no data was found for Portugal). One study, carried out in Italy in 2001-2002, showed that less than 5\% of patients had written ADs [15]. In Spain, the general population had very little knowledge about ADs [116-119] and in 2009 only $2 \%$ had written ADs [35].

Two issues that, as of yet, have received very little legal development, were identified in research from Spain: the idea that the process of thinking and talking about EoL decisions could be more useful than formal written living wills $[116,117,120]$; and the relevance of proxy decision-makers, which nowadays are usually designated verbally $[119,121]$.

\subsection{Medical EoL decisions}

Most of the reviewed research on EoL decisions was carried out with doctors (37 original studies), especially in Intensive Care Units (ICUs) (9 original studies). There were fewer studies conducted with the general population (8 original studies) or patients ( 2 original studies) and none with patients' family members.

International studies carried out in ICUs, showed that DoNot-Resuscitate orders (DNRs), withholding or withdrawing treatment, and doctor-assisted death, occurred less often in Southern Europe than in Western and Northern Europe [19,122-125]. Nevertheless, national level questionnaires with more representative samples suggested that DNRs, withholding and withdrawing treatment practices in Portugal and Spain are used more often than the results of international questionnaires suggest [126-128]. Contradictions between the findings from international and local/national questionnaires regarding the involvement of family members in EoL decisions made in ICUs were also identified. International surveys reported that discussion with patients and family members regarding DNRs, withholding and withdrawing treatment occurred less frequently in southern European countries compared to other countries [123,125], whereas national and local questionnaires reported that the majority of the doctors involve or consider that family members must be involved in decision-making [79,114,127].

The variety of ways in which medical doctors were questioned makes it difficult to compare their acceptance of euthanasia across the three countries. In Italy, the findings of three studies from the nineties indicated that between $15 \%$ and $18 \%$ of doctors were in favour of euthanasia [129-131]. However, when asked about specific situations, this percentage increased to between $32 \%$ and $40 \%$ [115,130,132]. A Portuguese study from 2009 reported that up to $39 \%$ of oncol- 
ogists favoured the legalisation of euthanasia [133]. Whereas a Spanish study from 2002 indicated that up to $60 \%$ of doctors believed that laws should be changed to allow patients to request and receive euthanasia and/or assisted suicide in the case of terminal illness [112]. Across the three countries, religion, sex, palliative care experience and years of practice were found to influence doctors' opinions [115,130-133].

Europe-wide surveys of the general public found that Italy and Portugal were among the countries with the lowest acceptance of euthanasia, whereas Spain occupied an intermediate position between the low and high acceptance countries [14]. In Italy, religion played an important role and the difference of opinions between believers and non-believers was higher than in the other countries [14]. Spain and Italy were found to have experienced a greater-than-average increase in euthanasia acceptance between 1981 and 1999 compared with a group of 12 western European countries [134]. Spanish surveys showed that acceptance of euthanasia in the specific case of terminal illness has been over 60\% since 1995 [35,135,136], higher among younger population groups [137], and reaching $81 \%$ in 2009 [35]. Spanish studies also demonstrated that the majority of the population was opposed to the use of life support measures in a situation of serious disease with no possibility of recovery $[35,52,138]$.

Among the studies identified from the three countries, more research articles were found concerning euthanasia (17), than assisted suicide (6). Both the general public in Spain and doctors in Portugal were more in favour of regulation for euthanasia than assisted suicide [35,133].

Terminal sedation was more accepted than euthanasia or physician-assisted suicide $[23,35,113]$ and more widely implemented in Italy than in other western European countries [139]. In the view of some experts, this was regarded as consistent with the Catholic tradition of opposition to euthanasia, but acceptance of pain relief to the point of sedation, even if death might be accelerated $[23,80,126]$. Moreover, terminal sedation was also considered consistent with the traditional Spanish perception that unconsciousness is the 'best way out' [23,140]. However, the debate continues: in Spain legal proceedings against the Leganés Hospital Emergency Unit have demonstrated that the boundary between euthanasia and terminal sedation is not totally clear [141], whereas some Italian authors have recently argued that sedation does not hasten death [22,142]. Part of the controversy relates to the use of terminal sedation to manage existential and family distress, which seemed more common in Spain than in other countries [143]. In Italy and Portugal, although some authors agreed that it might be difficult to distinguish pain from other kinds of suffering, terminal sedation for non-physical symptoms was rarely used $[22,142,144]$.

\subsection{Knowledge and attitudes towards care and death}

The attitudes of the general public and health professionals towards death were an important topic of study. In
Spain, several articles attempted to measure 'death anxiety' among health professionals [145-148], and among members of the general public [149-151]. Health professionals' anxiety tended to diminish with greater experience, but no clear relationship was found in either group between 'death anxiety' and religion [147,151]. In Italy, one study identified, between 1989 and 1999, a progressive secularization of the values around death [48]. Italian practising Catholics and non-believers were found to share concerns about the control of pain and symptoms, and a preference to die in a calm atmosphere and in the company of close relatives and friends $[46,48,152]$. The concerns and fears related to pain and the process of dying were also pre-eminent among both health professionals [153-156] and the general public in Spain [50,51,149,150,157].

Pain control strategies were mainly analyzed in articles from Italy (13 articles). The articles reported that a significant proportion of patients in studies from different parts of Italy failed to receive appropriate pain treatment [158-163]. These results from Italy are consistent with the European trend: the use of moderate doses of morphine; one third of patients assessed as in pain; and considerable variation in pain medication choices between countries [13]. In 2006, both Italy and Spain were below the European and global average of morphine consumption per capita, whereas Portugal was above the average [164]. Of the drugs used to alleviate symptoms with life-shortening as a possible side effect, Italian physicians were also found to administer opioids less often than their colleagues in Belgium, Denmark, The Netherlands, Sweden and Switzerland [165].

Different suggested explanations for low pain management included: lack of knowledge about adequate pain treatment [13]; underestimation of pain by professional caregivers [166]; health professionals', patients' and families' opiophobia [13,166-169]; Catholic ideals of pain endurance [167-169]; and problems of communication related to a lack of disclosure [170]. Opioid over-regulation was not a major limitation in the three countries [164]. In Italy, health professionals' knowledge about pain and analgesics was found to have improved between 1996 and 2003, and was better in emergency and anaesthesiology units than in the other units, and better among doctors than nurses [164,171-173]. In Spain, in the mid-nineties, nurses and nursing students did not show proper knowledge about pain control strategies [174,175].

Other aspects of palliative care were also found to be problematic for health professionals. In Spain, health professionals reportedly demanded specific training not only in pain management and other technical issues but also in psychosocial and emotional issues related with providing care to terminal patients [169,176-179]. In Italy, even though most of the doctors agreed that dealing with patients' emotions is important, they found it difficult [76]. General practitioners and older doctors were found to deal better with patients' anxiety and to be more emotionally protective [76]. 


\subsection{Informal caregivers}

In more than $84 \%$ of cases from Italy and Spain (no data for Portugal), patients' relatives (mainly daughters and wives) were identified as the main informal caregiver [38,41,101,180-186]. Women made up more than two thirds of caregivers in Italy, and more than three quarters in Spain $[38,41,101,180-186]$. Relatives provided care not only at home, but also in the hospitals, with a continuous presence in palliative care units [74]. A European comparative study on patients' last year of life found that the family was the main provider of support in Italy, Spain and Greece, whereas in other parts of Central and Northern Europe non-kin support was more prominent [21].

Care-giving was reported to have important consequences for relatives' quality of life: generally they felt overburdened [72,186-190]; lacked free time for themselves or other family members [179,181-183,191]; and, experienced multiple health problems that increased with the time dedicated to home care and with patients' worsening condition [185]. A nation-wide study in Italy showed that one-third of cancer patients' caregivers left paid employment, and that care-giving was a significant economic burden for a quarter of them [182,183,191]. Four studies reported a lack of knowledge of available EoL care services and subsidies in Spain (3) $[179,187,192]$ and Portugal (1) [190]. Also, Italian caregivers considered government economic subsidies insufficient and home assistance inadequate [181]. Specific problems depended on the situation of the caregivers: for young women in Portugal, care of their mothers radically altered their life and future plans [193].

Several negative portrayals of caregivers' contribution to EoL care were found. In Italy, doctors described relatives as a major factor in preventing the ideal practice of full disclosure and limitation of non-useful treatment $[77,78,114]$. Two concepts with negative connotations were identified: the 'conspiracy of silence' in Spain and Italy $[60,73,84,143]$, the partial or non-disclosure which is frequently attributed to family members; and, 'claudicación familiar' (family surrender) in Spain, when patients die in hospital and not at home (the ideal place of death according to health professionals) [194].

\subsection{Qualitative research}

Of the 208 original studies considered relevant to understanding the role of culture in EoL care, around one fifth (44) used qualitative techniques. The number is even lower (34) if studies that just used content analysis to design or obtain quantitative data and only analyzed open questions from mainly quantitative questionnaires are excluded. Of the 34 articles one was a Delphi study, looking for consensus regarding euthanasia in Spain [195]. Another study used an ethnoscience approach to analyze patients' perceptions of fatigue [196]. Two studies used case studies [193,197] for very specific patients groups.
Twenty-four used semi-structured or in-depth interviews and group discussions, with a large variety in their topic of interest and quality of methods: three for Portugal $[189,198,199]$, four for Italy $[92,97,152,200]$, sixteen for Spain $[81,84,117,120,140,187,192,201-209]$, and one international study that includes data from Spain and Italy [210]. Finally, six articles (using data from four different studies) included long-term participant observation. Only one $[168,169]$ of these four studies was totally focused on EoL care and the other three were wider studies on cancer $[101,104,105]$ or intensive care units [211]. Three of these studies were focused on professionals' perspectives $[101,168,169,211]$, and only one took a holistic view and included the perspectives of patients and relatives $[104,105]$.

\section{Discussion}

The different palliative care systems and histories in Spain, Italy and Portugal are embedded in cultural contexts that share some characteristics but also have important differences. The main cultural factors, shared between the three countries and stressed in the literature, are the importance of family and community ties, and Catholicism.

\subsection{Shared cultural factors: strong family ties and Catholic tradition}

Given the stereotype of these countries as places where social and family links are stronger than in the rest of Europe, it is often assumed that in Portugal, Italy and Spain, people die mainly at home, surrounded by their loved ones. However, only in Italy, particularly in the southern region, does the majority of the population die at home. Preferences for home as the place of care and death are however higher, and this suggests that there may be practical barriers to providing EoL care at home. Nevertheless, four articles emphasize the relationship between the lack of health and social services and home deaths, especially in Italy [21,31,45,47], and in Spain, half of the population has recently expressed a preference for hospice or hospital care [35]. In this context, where informal caregivers are also overburdened, preference for home death should not be used as a justification for the sole prioritization of domiciliary care that may be more related to attempts to limit healthcare expenditure [23].

The importance of diagnosis and prognosis disclosure in the Spanish, Italian and Portuguese literature contrasts with the findings from reviews of the literature on culture and EoL in other European countries which give far less attention to the issue [27]. Again, the role of the family and the community has been considered crucial to explaining southern European perspectives, and the traditional Catholic approach to truth has also been considered relevant. The difference between, on one hand, the opinions and preferences of both health professionals and the general public (which have increasingly moved towards full disclosure) and on the other hand, 
the real practices (the development of which is not clear) demonstrates the importance of not limiting social and cultural research in EoL to preferences and opinions. It is also necessary to describe and analyze practices and explain why they vary from stated preferences and theoretical models.

In Spain, there are also differences between common practices, legal ideals and professionals' opinions regarding ADs. In terms of disclosure and ADs, the ideals, influenced strongly by the hegemonic 'Anglo-Saxon' values of medicine, tend to prioritize autonomy and rational choice, whereas in practice, the logics of care [212] and beneficence seem more prevalent. Also, in both cases, analysis of and reflection on the differences between ideals and practice have had an impact on experts' discussions. Southern European experiences, along with those from other 'non-Western' countries, have enriched the debate, uncovering the complexities of patientdoctor communication and decision-making processes, and the importance of the role of family in EoL care.

The principal cultural factor stressed in the articles on medical EoL decisions is religion. Catholicism has been considered a key factor explaining the more pro-life profile of Spanish, Italian and Portuguese medical EoL decisions and the preferences for terminal sedation compared to other EoL medical practices. It has also proved to be a key reason for the differences in opinions and practices of doctors and the general public in the three countries. Only a few articles questioned the role of the family in medical EoL decisions, and it was always from the point of view of the health professionals $[79,114,127]$. Given the active role of the family during EoL care, there is a need for research on the perspectives of relatives and informal caregivers.

For the general public, pain is the main death-related concern, but it is frequently undertreated. Various articles stress that there are differences in pain management between European countries and recognize that different cultural factors may be involved $[13,165,166,170]$. In most cases, all European countries share these cultural factors. Nevertheless, there are two suggested factors that may have a specific impact in Italy, Spain and Portugal: Catholic views on pain endurance, and communication problems related to lack of disclosure. Further research is however needed to demonstrate their relevance for EoL care and total pain management in specific contexts.

Up to now, the family and Catholicism have been described as the main explanatory cultural factors underlying characteristics of EoL care shared by Portugal, Spain and Italy. Relatives are involved during the whole EoL care process: caring for the patient at home; accompanying the patient most of the time in the hospital; worrying about the patients' pain; and participating in disclosure, ADs and other EoL decisions. Catholic traditions have influenced medical paternalism, gradual disclosure, pro-life positions, negative attitudes towards withholding and withdrawal of treatment, preferences for sedation over other EoL options, and approaches to death and pain in these countries. However, reflection on the role of the family and religion in EoL care is not, and should not, be restricted to these countries: family and religion also influence EoL care in all countries, in different ways in every local context. Nor should reflections be restricted to simplistic univocal relations or generalizations for one or several countries. Simplified, limited understandings of culture and cultural factors have repeatedly been shown to have greater political than interpretative power, and run the risk of stereotyping $[4,213]$.

\subsection{Cultural analysis and improvement of EoL care in Italy, Spain and Portugal}

There are three ways that an analysis of culture in Italy, Spain and Portugal could contribute to the improvement of EoL care. Firstly, a deeper analysis of the role of both family ties and religion is required.

In a context where family structures are changing and informal caregivers are clearly overburdened, an improved understanding of family dynamics during EoL care is crucial to improve care. Relatives cannot be excluded from the debate, as sometimes happens when Anglo-Saxon practices, such as ADs, are adopted uncritically in these countries. The negative images of caregivers' contribution to EoL care also deserve more detailed study, as they point to a new example of 'victim blaming'. Finally, given the preponderance of female caregivers, it is necessary to include a gender perspective in analysis.

Regarding Catholicism, at least two different ways of understanding religion have been included in this review: the Catholic cultural tradition, which involves a number of values that are clearly shared by many with a Catholic identity, but have also permeated society in general $[23,24,80,126,167-169]$; and the personal experience of religion, which may include a person's the self-definition as Catholic [14,115,130-133,151], and the degree to which religious practices are followed [147]. The anthropological perspective differs from the use of religion in quantitative research as an isolated variable based on self-definition and from religious and experiential views. Here, these two understandings of religion are considered to influence each other, to be interrelated and difficult to separate. With this perspective in mind, it is essential to reflect on the process of secularization: nowadays non-believers make up a significant proportion of the population in these countries. The tensions between conservative religious and progressive secular groups are evident in the debates concerning high-profile medical cases in both Italy and Spain, and it is important to analyze the complex intertwinement in these countries of politics and religion.

Secondly, cultural analysis should not be restricted to the family and religion, which are topics widely cited in the literature. Anthropological analysis is useful to understand EoL care in the context of social relations, needs, values, interests and power positions of the different actors involved in the process. This analysis should be carried out in specific contexts and take into account differences and inequalities in 
the provision of medical and social resources between countries and regions. Local analysis does not only enable the identification of similarities, but also promotes understanding of variability, the differences between and within countries. Such analysis will help to answer some of the questions that have emerged from the quantitative data synthesized in this review: what underlies the greater preferences for open disclosure in Porto compared with other populous cities in Spain and Italy? Why is the use of morphine lower in Spain and Italy than in Portugal when their palliative care systems are more developed? What are the factors that explain the more favourable view of euthanasia and the legal development of ADs in Spain? How can the differences in place of care and death between Italy, on one hand, and Spain and Portugal on the other be understood? What is the meaning of the use of terminal sedation to manage existential and family distress that only seems to be accepted in Spain?

Finally, the third contribution of cultural analysis is related to its focus on practice. In the literature review, multiple normative approaches to EoL care have emerged: bioethicists' analysis of disclosure or medical EoL decisions in the light of bioethical principles; psychologists' approach to ideal ways of communication; legal defences of patients' rights; and, theoretical preferences and values of professionals and the general public. However, it has become clear that practices are not always consistent with the normative approaches. Qualitative analysis of what happens in the final stages of life, would complement quantitative descriptions and correlations of practices to achieve a better understanding of the practical, performative logics. It would also help in the description of the constraints that limit the approximation of practices to theoretical, ideal models.

In these ways, locally focused qualitative studies that maintain broad research questions open important possibilities for a better understanding of EoL care. The critics of qualitative research would argue that such an approach yields data that is not easily generalisable to a national level, which complicates cross-country comparison. As we have seen in the review, this is not only a limitation of qualitative research. Contradictions were also found in the results of quantitative studies depending on the representativeness of the study samples, and the design of questionnaires and closed nature of the questions and answers. This review has also shown that most qualitative research on EoL care carried out to date in Italy, Spain and Portugal has consisted of small, partial studies with very specific topics and not with the holistic objective of understanding the whole, complete EoL process. More comprehensive qualitative studies can generate insights that are relevant nationally.

\section{Concluding remarks}

A synthesis of the cultural factors involved on EoL care in Southern Europe is always at risk of reinforcing a simplified, stereotypical portrayal of a place where most people are cared by their families and die at home without being aware of their diagnosis, where palliative care services are less developed, medical EoL decisions occur less frequently, and patients are less involved in decision making than in northern Europe. Some of these characteristics can be used appropriately to describe specific situations in particular areas of Southern Europe, but the reality is far more diverse and complex.

In this article the similarities and differences in EoL care between Italy, Spain and Portugal, and within each of these countries have been described. Gaps in research on culture and EoL care have also been identified and a cultural approach, which could be useful to avoid stereotypes and to understand and improve EoL in these countries, has been suggested. A locally-focused approach that interrelates values and practices, does not exclude any of the actors in EoL care, including the family, and dialogues with the quantitative literature can help to improve communication, decision-making and care processes in concrete and flexible social, cultural and institutional contexts.

\section{Conflict of interest}

The authors of this review have no conflict of interest.

\section{Reviewers}

Antonella Surbone, MD PhD FACP, Adjunct Professor of Medicine, New York University, via San Damiano 11, I20122 Milan, Italy.

Prof. Josep Maria Comelles, PhD, Universitat Rovira i Virgili, Pl. Imperial Tarraco 1, E-43005 Tarragona, Catalunya, Spain.

\section{Acknowledgements}

PRISMA is funded by the European Commission's Seventh Framework Programme (contract number: HealthF2-2008-201655) with the overall aim to co-ordinate high-quality international research into end-of-life cancer care. PRISMA aims to provide evidence and guidance on best practice to ensure that research can measure and improve outcomes for patients and families. PRISMA activities aim to reflect the preferences and cultural diversities of citizens, the clinical priorities of clinicians, and appropriately measure multidimensional outcomes across settings where end-of-life care is delivered. Principal Investigator: Richard Harding. Scientific Director: Irene J. Higginson. In recognition of the collaborative nature of PRISMA, the authors thank the following PRISMA members: Gwenda Albers, Barbara Antunes, Ana Barros Pinto, Claudia Bausewein, Dorothee Bechinger-English, Hamid Benalia, Lucy Bradley, Lucas Ceulemans, Barbara A. Daveson, Luc Deliens, Noël Derycke, Martine de Vlieger, Let Dillen, Julia Downing, 
Michael Echteld, Natalie Evans, Dagny Faksvåg Haugen, Lindsay Flood, Nancy Gikaara, Barbara Gomes, Marjolein Gysels, Sue Hall, Richard Harding, Irene J Higginson, Stein Kaasa, Jonathan Koffman, Pedro Lopes Ferreira, Johan Menten, Natalia Monteiro Calanzani, Fliss Murtagh, Bregje Onwuteaka-Philipsen, Roeline Pasman, Francesca Pettenati, Robert Pool, Tony Powell, Miel Ribbe, Katrin Sigurdardottir, Steffen Simon, Franco Toscani, Bart van den Eynden, Jenny van der Steen, Paul Vanden Berghe, and Trudie van Iersel.

\section{References}

[1] Corrales Baz E, Codorniu Zamora N, Borrell Busquets R, Trelis Navarro J. Dimensión sociocultural de la alimentación en Cuidados Paliativos. Med Paliativa 2002;9(3):139-42.

[2] Firth S. Wider horizons: care of the dying in a multicultural society. London: National Council for Hospice and Specialist Palliative Care Services; 2001.

[3] Badger F, Pumphrey R, Clarke L, et al. The role of ethnicity in end-oflife care in care homes for older people in the UK: a literature review. Divers Health Care 2009;6(1):23-9.

[4] Lock M, Nguyen VK. An anthropology of biomedicine. West Sussex: Wiley-Blackwell; 2010.

[5] Meñaca A. Sistema sanitario e inmigración. El papel de la cultura. In: Esteban ML, editor. Introducción a la antropología de la salud. Bilbao: OSALDE; 2007. p. 103-16.

[6] van Dijk R. Culture as excuse: the failures of health care to migrants in Netherlands. In: van der Geest S, Rienks A, editors. The art of medical anthropology. Readings. Amsterdam: Het Spinhuis; 1998. p. 243-50.

[7] Owens A, Randhawa G. 'It's different from my culture; they're very different': providing community-based, 'culturally competent' palliative care for South Asian people in the UK. Health Soc Care Commun 2004;12(5):414-21.

[8] Gunaratman Y. Intercultural palliative care: do we need cultural competence? Int J Palliat Nurs 2007;13(10):470.

[9] Surbone A. Cultural aspects of communication in cancer care. Support Care Cancer 2008;16:235-40.

[10] Hahn RA, Kleinman A. Biomedical practice and anthropological theory: frameworks and directions. Annu Rev Anthropol 1983;12:305-33.

[11] Foley R-A, Papadaniel Y, Kaech F, Rossi I. From curative to palliative care: confronting the new medical realities in a hospitalised way of life. In: Fainzang S, Hem HE, Bech Risor M, editors. The taste for knowledge. Medical anthropology facing medical realities. Aarhus: Aarhus University Press; 2010. p. 219-36.

[12] Vecchio Good MJ, Good BJ, Schaffer C, Lind SE. American oncology and the discourse on hope. Cult Med Psychiatry 1990;14(1):59-79.

[13] Klepstad P, Kaasa S, Cherny N, et al. Pain and pain treatments in European palliative care units. A cross sectional survey from the European Association for Palliative Care Research Network. Palliat Med 2005;19(6):477-84.

[14] Cohen J, Marcoux I, Bilsen J, Deboosere P, Van der Wal G, Deliens L. European public acceptance of euthanasia: socio-demographic and cultural factors associated with the acceptnce of euthanasia in 33 European countries. Soc Sci Med 2006;63(3):743-56.

[15] van der Heide A, Deliens L, Faisst K, et al. End-of-life decisionmaking in six European countries: descriptive study. Lancet 2003;362:345-50.

\footnotetext{
${ }^{1}$ Included only those references cited in the article. For a full list of the references in the review please refer to Evans et al. [27].
}

[16] Vincent JL. Ethical principles in end-of-life decisions in different European countries. Swiss Med Wkly 2004;134(5-6):65-8.

[17] Holland JC, Geary N, Marchini A, Tross S. An international survey of physician attitudes and practice in regard to revealing the diagnosis of cancer. Cancer Invest 1987;5(2):151-4.

[18] Thomsen OO, Wulff HR, Martin A, Singer PA. What do gastroenterologists in Europe tell cancer patients? Lancet 1993;341: 473-6.

[19] Sprung C, Cohen S, Sjokvist P, et al. End-of-life practices in European intensive care units The Ethicus Study. J Am Med Assoc 2003;290(6):790-7.

[20] Vincent JL. Cultural differences in end-of-life care. Crit Care Med 2001;29(2 Suppl.):N52-5.

[21] Hank K, Jurges H. The last year of life in Europe: regional variations in functional status and sources of support. Ageing Soc 2010;30:1041-54.

[22] Mercadante S, Intravaia G, Villari P, Ferrera P, David F, Casuccio A. Controlled sedation for refractory symptoms in dying patients. J Pain Symptom Manage 2009;37(5):771-9.

[23] Núñez Olarte JM, Gracia Guillén D. Cultural issues and ethical dilemmas in palliative and end-of-life care in Spain. Cancer Control 2001;8(1):46-54.

[24] Toscani F, Farsides C. Deception, catholicism, and hope: understanding problems in the communication of unfavorable prognoses in traditionally-Catholic countries. Am J Bioeth 2006;6(1):W6-18.

[25] Harding R, Higginson IJ. PRISM.A: a pan-European co-ordinating action to advance the science in end-of-life cancer care. Eur J Cancer 2010;46(9):1493-501.

[26] Perdiguero E, Comelles JM. Medicina y cultura. Estudios entre la antropología y la medicina. Barcelona: Edicions Bellaterra; 2000.

[27] Evans N, Meñaca A, Andrew EVW, Pool R, Gysels M. PRISMA WP1. Culture and end-of-life care: a scoping exercise of eight European countries. Barcelona: Barcelona Centre for International Health Research (CRESIB); 2009.

[28] Centeno C, Clark D, Lynch T, et al. Facts and indicators on palliative care development in 52 countries of the WHO European region: results of an EAPC task force. Palliat Med 2007;21:463-71.

[29] DeConno F, Caraceni A, Groff L, et al. Effect of home care on the place of death of advanced cancer patients. Eur J Cancer 1996;32A(7):1142-7.

[30] Monti M, Cunietti E, Castellani L, Merli M, Cruciatti F. Ten years' activity of the first Italian public hospice for terminally ill patients. Support Care Cancer 2004;12(11):752-7.

[31] Beccaro M, Costantini M, Merlo DF, et al. Inequity in the provision of and access to palliative care for cancer patients. Results from the Italian survey of the dying of cancer (ISDOC). BMC Public Health 2007;7:66.

[32] Centeno C, Hernansanz S, Flores LA, Rubiales AS, López-Lara F. Spain: palliative care programs in a national, survey. J Pain Symptom Manage 2002;24(2):245-51.

[33] Di Mola G, Ventafridda V, Crisci MT. Indagine sulla conoscenza delle cure palliative nella popolazione italiana. Riv Ital di Cure Palliative 2001;1(3):15-8.

[34] APEME. Os cuidados paliativos em Portugal. Resultados Quantitativos: APEME; 2008. Available in: http://www.apcp.com.pt.

[35] CIS. Atención a pacientes con enfermedades en fase terminal. Estudio 2803. Madrid: CIS; 2009.

[36] Instituto Nacional de Estatística de Portugal. Óbitos por distribuição geográfica de residência (NUTS II) e sexo, segundo a causa de morte. Lisboa: Instituto Nacional de Estatística de Portugal; 2005.

[37] Belderrain Belderrain P, García Busto B, Castañón Quiñones EC. Atención sanitaria y comunicación con el enfermo oncológico en situación terminal y su familia en un área de salud. Aten Primaria 1999;24(5):285-8.

[38] Catalán-Fernández JG, Pons-Sureda $\mathrm{O}$, Recober-Martínez A, et al Dying of cancer. The place of death and family circumstances. Med Care 1991;29(9):841-52. 
[39] Gómez Batiste X, Viladiu P, Fontanals MD, et al. Morir de cáncer en Cataluña: estudio poblacional sobre el último mes de vida de pacientes con cáncer (1993-94). Med Paliativa 2001;8(3):134-7.

[40] Jimeno Aranda A, Catalán R, García Ruiz M, Benedi E, Fernández Picó A, Usoz R. ¿Dónde fallece el paciente terminal? Aten Primaria 1993;11(3):120-2.

[41] Lafuerza A, Alcalde R, Roca J, et al. Morir de cáncer en Cataluña. Encuesta a cuidadores de pacientes fallecidos por cáncer. Estudio multicéntrico de la utilización de mórficos en pacientes terminales. Oncología (Barcelona) 1998;21(4):91-4.

[42] Olano Espinosa E, Alonso Pérez JL, Crespo Garzón A, Sionis A, Sabugal Rodelgo G, Velázquez García A. Atención al paciente oncológico terminal en un distrito de atención primaria. Aten Primaria 1997;19(9):483-6.

[43] Ramón I, Alonso J, Subirats E, et al. El lugar de fallecimiento de las personas ancianas en Cataluña. Rev Clin Esp 2006;206(11):549-55.

[44] Cohen J, Houttekier D, Onwuteaka-Philipsen B, et al. Which patients with cancer die at home? A study of six European countries using death certificate data. J Clin Oncol 2010;28(13):2267-73.

[45] Beccaro M, Costantini M, Rossi PG, et al. Actual and preferred place of death of cancer patients. Results from the Italian survey of the dying of cancer (ISDOC). J Epidemiol Commun Health 2006;60(5):412-6.

[46] Di Mola G, Crisci MT. Attitudes towards death and dying in a representative sample of the Italian population. Palliat Med 2001;15(5):372-8.

[47] Spataro R, Lo Re M, Piccoli T, Piccoli F, La Bella V. Causes and place of death in Italian patients with amyotrophic lateral sclerosis Acta Neurol Scand 2010;122(3):217-23.

[48] Toscani F, Cantoni L, Di Mola G, Mori M, Santosuosso A, Tamburini M. Death and dying: perceptions and attitudes in Italy. Palliat Med 1991;5(4):334-43.

[49] Arana M, Martín I, Guillén MV, Ibero JL, Marzo J, Delgado MT. Actitudes ante la enfermedad terminal. Encuesta a usuarios de un centro de salud. Aten Primaria 1993;12(8):523.

[50] Fernández Díaz R, Pérez Suárez MC, Cossío Rodríguez I, Martínez González P. Actitud ante una enfermedad incurable. Aten Primaria 1996;17(6):389-93.

[51] Fernández Suárez A, Fernández Álvarez T, Alonso Arruquero C, et al. Actitud de los usuarios de centro de salud ante el diagnóstico de enfermedad terminal. Aten Primaria 2002;30(7):449-54

[52] Wanden-Berghe C, Guardiola-Wanden-Berghe R, Sanz-Valero J. Red de Malnutrición en Iberoamérica. Voluntades de la población sobre los cuidados y decisiones al final de la vida. Nutr Hosp 2009;24(6): $732-7$.

[53] Formiga F, Chivite D, Ortega C, Casas S, Ramón JM, Pujol R. Endof-life preferences in elderly patients admitted for heart failure. Q J Med 2004;97(12):803-8.

[54] Bajo García J, García García JA, Landa Petralanda V, Marijuán Arcocha L, Rodríguez Salvador JJ. Cuidado del enfermo terminal visto por el médico de familia. Aten Primaria 1990;7(9):12-24.

[55] Osuna E, Pérez-Cárceles MD, Esteban MA, Luna A. The right to information for the terminally ill patient. J Med Ethics 1998;24(2): $106-9$.

[56] Porta M, Busquet X, Jariod M. Attitudes and views of physicians and nurses towards cancer patients dying at home. Palliat Med 1997;11(2):116-26.

[57] Sanz de la Torre JC, Peña Tejeiro E, Gómez Galán R, Garrido González J, Herrero Olea A. Actitudes del enfermero/a ante el paciente terminal. Enfermería Científica 2000;220-221:17-20.

[58] Surbone A. Information to the cancer patient: psychosocial and spiritual implications. Support Care Cancer 1993;1(2):89-91.

[59] Centeno Cortes C, Núñez Olarte JM. Estudios sobre la comunicación del diagnóstico del cáncer en España. Med Clin (Barc) 1998;110(19):744-50.

[60] Surbone A, Ritossa C, Spagnolo AG. Evolution of truthtelling attitudes and practices in Italy. Crit Rev Oncol Hematol 2004;52(3):165-72.
[61] Andruccioli J, Montesi A, Di Leo S, et al. Illness awareness in hospice: application of a semi-structured interview. Am J Hosp Palliat Care 2009;26(5):384-91.

[62] Andruccioli J, Montesi A, Raffaeli W, et al. Illness awareness of patients in hospice: psychological evaluation and perception of family members and medical staff. J Palliat Med 2007;10(3):741-8.

[63] Caruso A, Di Francesco B, Pugliese P, Cinanni V, Corlito A. Information and awareness of diagnosis and progression of cancer in adult and elderly cancer patients. Tumori 2000;86:199-203.

[64] Corli O, Apolone G, Pizzuto M, et al. Illness awareness in terminal cancer patients: an Italian study. Palliat Med 2009;23(4):354-9.

[65] Morasso G, Alberisio A, Capelli M, Rossi C, Baracco G, Costantini M. Illness awareness in cancer patients: a conceptual framework and a preliminary classification hypothesis. Psychooncology 1997;6:212-7

[66] Pronzato P, Bertelli G, Losardo P, Landucci M. What do advanced cancer patients know of their disease? A report from Italy. Support Care Cancer 1994;2(4):242-4.

[67] The Italian Group for the Evaluation of Outcomes in Oncology (IGEO). Awareness of disease among Italian cancer patients: is there a need for further improvement in patient information? Ann Oncol 1999;10:1095-100.

[68] Veronesi A, Busato C, Annunziata MA, et al. Prospective analysis of the information level of Italian cancer patients. Eur J Cancer 1995;31A(3):425-6.

[69] Welshman A. From Italy. Palliat Med 2003;17(2):122-3.

[70] Costantini M, Morasso G, Montella M, et al. Diagnosis and prognosis disclosure among cancer patients. Results from an Italian mortality follow-back survey. Ann Oncol 2006;17(5):853-9.

[71] Centeno-Cortes C, Núñez-Olarte JM. Questioning diagnosis disclosure in terminal cancer patients: a prospective study evaluating patients' responses. Palliat Med 1994;8(1):39-44.

[72] Gómez Pavón FJ. Características del anciano con enfermedad oncológica en fase terminal en el medio hospitalario sociosanitario. Universidad Complutense de Madrid, Servicio de Publicaciones; 2002.

[73] Ruiz-Benítez de Lugo MA, Coca MC. El pacto de silencio en los familiares de los pacientes oncológicos terminales. Psicooncología 2008;5(1):53-69.

[74] Fainsinger RL, Núñez-Olarte JM, Demoissac DM. The cultural differences in perceived value of disclosure and cognition: Spain and Canada. J Palliat Care 2003;19(1):43-8.

[75] Poveda de Agustín J. Información al paciente terminal: un reto antropológico. Jano 1992;1009:93-106.

[76] Annunziata M, Talamini R, Tumolo S, Rossi C, Monfardini S. Physicians and death: comments and behaviour of 605 doctors in the north-east of Italy. Support Care Cancer 1996;4(5):334-40.

[77] Dataanalysis. La comunicazione della diagnosi e prognosi in oncologia; 2003, http://saluteeuropa.it/index.php/salute_europa/ News/La_comunicazione_della_diagnosi_e_prognosi_in_oncologia.

[78] Grassi F, Giraldi T, Messina EG, Magnani K, Valle E, Cartei G. Physicians' attitudes to and problems with truth-telling to cancer patients. Support Care Cancer 2000;8:40-5.

[79] Lucchiari C, Masiero M, Pravettoni G, Vago G, Wears RL. End-oflife decision-making: a descriptive study on the decisional attitudes of Italian physicians. Life Span Disabil 2010;13(1):71-86.

[80] Domínguez B, Urraca Martínez S. Opiniones de los médicos y enfermeras sobre el dolor y la muerte de pacientes terminales. Jano 1985;654-H:57-68.

[81] García Caro MP, Río-Valle JS, Quintana FC, Peña DP, Vinuesa AM, Athanasios P. Enfermedad terminal. Muerte en palabras de los profesionales (I). Un estudio cualitativo de entrevistas en profundidad a profesionales de la salud. Rev Enferm 2008;31(5): 54-8.

[82] López de Maturana A, Morago V, San Emeterio E, Gorostiza J, Arrate AO. Attitudes of general practitioners in Bizkaia, Spain, towards the terminally ill patient. Palliat Med 1993;7(1):39-45. 
[83] Pacheco R, Osuna E, Gómez Zapata M, Luna A. Attitudes of medical personnel (doctors and nurses) toward informing the terminal patient. Med Law 1989;8(3):243-8.

[84] Río-Valle J, Paz M, Caro G, et al. Bad news for the patient and the family? The worst part of being a health care professional. J Palliat Care 2009;25(3):191-6.

[85] Gonçalves F, Marques A, Rocha S, Leitão P, Mesquita T, Moutinho S. Breaking bad news: experiences and preferences of advanced cancer patients at a Portuguese oncology centre. Palliat Med 2005;19(7):526-31.

[86] Pimentel FL, Ferreira JS, Real MV, Mesquita NF, Maia-Gonçalves JP. Quantity and quality of information desired by Portuguese cancer patients. Support Care Cancer 1999;7(6):407-12.

[87] Surbone A. Information, truth, and communication. For an interpretation of truth-telling practices throughout the world. Ann N Y Acad Sci 1997;809:7-16.

[88] Spinsanti S. Obtaining consent from the family: a horizon for clinical ethics. J Clin Ethics 1992;3:188-92.

[89] Brusamolino E, Surbone A. Telling the truth to the patient with cancer. A cross-cultural dialogue. Ann N Y Acad Sci 1997;809:411-21.

[90] Surbone A, Zwitter M. Learning from the world. The editor's perspective. Ann N Y Acad Sci 1997;809:1-6.

[91] Annunziata MA. Ethics of relationship. From communication to conversation. Ann N Y Acad Sci 1997;809:40-55.

[92] Ghinelli C, Dini D, Comelli D, Piccinini L. Welcome meetings with patients' families: a qualitative research conducted in an Italian hospice. Psychooncology 2007;16:S214-5.

[93] Higginson IJ, Costantini M. Communication in end-of-life cancer care: a comparison of team assessments in three European countries. J Clin Oncol 2002;20(17):3674-82.

[94] Mauri E, Vegni E, Lozza E, Parker PA, Moja EA. An exploratory study on the Italian patients' preferences regarding how they would like to be told about their cancer. Support Care Cancer 2009;17(12):1523-30.

[95] Morasso G, Capelli M, Viterbori P, et al. Psychological and symptom distress in terminal cancer patients with met and unmet needs. J Pain Symptom Manage 1999;17(6):402-9.

[96] Paci E. The process of communication of the diagnosis: psychological, ethical and cultural aspects. New Trends Exp Clin Psychiatry 1997;13(1):59-63.

[97] Piredda M, De Marinis MG, Rocci L, Gualandi R, Tartaglini D, Ream E. Meeting information needs on cancer-related fatigue: an exploration of views held by Italian patients and nurses. Support Care Cancer 2007;15(11):1231-41.

[98] Galeazzi O. Truth, disease, and prognosis, an historicalanthropological analysis. Ann N Y Acad Sci 1997;809:40-55.

[99] Surbone A. Telling the truth to patients with cancer: what is the truth? Lancet Oncol 2006;7:944-50.

[100] Wood WA, McCabe MS, Goldberg RM. Commentary: disclosure in oncology - to whom does the truth belong? Oncologist 2009;14(1):77-82

[101] González Barón M, Díaz Martínez F, Ordóñez Gallego A. La relación médico-paciente en oncología: una visión sociológica. Barcelona: Rubí; 2002.

[102] Campione F, Chiappinelli RC, Alessi G. To die without speaking of death. Mortality 2004;9(4):345-9.

[103] Davis DP. Cultural differences and the practice of medicine. Health Care Anal 1993;1(1):101-2.

[104] Gordon DR. Embodying illness, embodying cancer. Cult Med Psychiatry 1990;14(2):275-97.

[105] Gordon DR, Paci E. Disclosure practices and cultural narratives: understanding concealment and silence around cancer in Tuscany, Italy. Soc Sci Med 1997;10:1433-52.

[106] Bock M, Ciarrocchi V, Wiedermann CJ. Case involving end-of-life decision issues in Italy. Intensive Care Med 2007;33(6):1041-2

[107] Maggiore SM, Antonelli M. Euthanasia, therapeutic obstinacy or something else? An Italian case. Intensive Care Med 2005;31: $997-8$.
[108] Servillo G, Striano P. End-of-life: still an Italian dilemma. Intensive Care Med 2008;34(7):1333-5.

[109] Zamperetti N, Proietti R. End of life in the ICU: laws, rules and practices: the situation in Italy. Intensive Care Med 2006;32: $1620-2$.

[110] Pereira A. Advance directives: binding or merely indicative? Incoherence of the Portuguese National Council of Ethics for the Life Sciences and insufficiencies of newly proposed regulation. Eur J Health Law 2009;16(2):165-71.

[111] Simón-Lorda P, Tamayo-Velázquez MI, Barrio-Cantalejo IM. Advance directives in Spain. Perspectives from a medical bioethicist approach. Bioethics 2008;22(6):346-54.

[112] CIS. Actitudes y opiniones de los médicos ante la eutanasia. Estudio 2451. Madrid: CIS; 2002.

[113] Catania C, Zagonel V, Fosser V, et al. Opinions concerning euthanasia, life-sustaining treatment and acceleration of death: results of an Italian Association of Medical Oncology (AIOM) survey. Ann Oncol 2008;19(11):1947-54.

[114] Giannini A, Pessina A, Tacchi EM. End-of-life decisions in intensive care units: attitudes of physicians in an Italian urban setting. Intensive Care Med 2003;29:1902-10.

[115] Canova C, Miccinesi G, Bensenati P, et al. End-of-life medical decisions: a study on the physicians's opinions in four Italian centres. Epidemiol Prev 2006;30:269-78.

[116] López-Rey EA, Romero-Cano M, Tébar-Morales JP, Mora-García $\mathrm{C}$, Fernández-Rodríguez O. Conocimiento y actitudes de la población sobre el documento de voluntades previas. Enferm Clin 2008;18(3):115-9.

[117] Lorente López M. Las voluntades anticipadas en el ámbito de la salud: opiniones y actitudes de la población de la zona de salud urbana Torre Ramona de Zaragoza. Trabajo Social y Salud 2004;49:83-122.

[118] Miró G, Pedrol E, Soler A, et al. Conocimiento de la enfermedad y de los documentos de voluntades anticipadas en el paciente sepropositivo por el VIH. Med Clin (Barc) 2006;126(15):567-72.

[119] Solsona JF, Sucarrats A, Maull E, Barbat C, García S, Villares S Toma de decisiones al final de la vida. Encuesta sobre la actitud ante la muerte en el paciente crítico. Med Clin (Barc) 2003;120(9): $335-6$.

[120] Abad-Corpa E, García-Palomares A, Martínez-Rodríguez S, SánchezPérez R, Molina-Ruiz A. Exploración del fenómeno de la planificación anticipada de decisiones al final de la vida: visión de los profesionales que cuidan a personas mayores. Enferm Clin 2006;16(3):127-36.

[121] Rodríguez Jornet A, Ibeas J, Real J, Peña S, Martínez Ocaña JC, García García M. Documento de voluntades anticipadas de pacientes con insuficiencia renal crónica terminal en tratamiento sustitutivo mediante diálisis. Nefrología 2007:581-92.

[122] Fissell RB, Bragg-Gresham JL, Lopes AA, et al. Factors associated with "do not resuscitate" orders and rates of withdrawal from hemodialysis in the international DOPPS. Kidney Int 2005;68(3):1282-8.

[123] Vincent JL. European attitudes towards ethical problems in intensive care medicine: results of an ethical questionnaire. Intensive Care Med 1990;16(4):256-64.

[124] Vincent JL. Information in the ICU: are we being honest with our patients? The results of a European questionnaire. Intensive Care Med 1998;24:1251-6.

[125] Vincent JL. Forgoing life support in western European intensive care units: the results of an ethical questionnaire. Crit Care Med 1999;27(8):1626-33.

[126] Abizanda Campos R, Almendros Corral L, Balerdi Perez B, Socias Crespi L, López Ferre J, Valle Herraez FX. Limitación del esfuerzo terapéutico. Encuesta sobre el estado de opinión de los profesionales de la medicina intensiva. Med Intensiva 1994;18(3):100-5.

[127] Esteban A, Gordo F, Solsona JF, et al. Withdrawing and withholding life support in the intensive care unit: a Spanish prospective multicentre observational study. Intensive Care Med 2001;27:1744-9. 
[128] Cardoso T, Fonseca T, Pereira S, Lencastre L. Life-sustaining treatment decisions in Portuguese intensive care units: a national survey of intensive care physicians. Crit Care 2003;7(6):R167-75.

[129] Crisci C, Guariglia M, Gargano F, Caruso G. Italian neurologists and euthanasia. A poll. Ital J Neurol Sci 1992;13(5):425-7.

[130] Grassi L, Agostini M, Magnani K. Attitudes of Italian doctors to euthanasia and assisted suicide for terminally ill patients. Lancet 1999;354(9193):1876-7.

[131] Grassi L, Magnani K, Ercolani M. Attitudes toward euthanasia and physician-assisted suicide among Italian primary care physicians. J Pain Symptom Manage 1999;17(3):188-96.

[132] DiMola G, Borsellino P, Brunelli C, et al. Attitudes toward euthanasia of physician members of the Italian Society for Palliative Care. Ann Oncol 1996;7(9):907-11.

[133] Gonçalves F. Attitudes toward assisted death amongst Portuguese oncologists. Support Care Cancer 2010;18:3359-66.

[134] Cohen J, Marcoux I, Bilsen J, Deboosere P, van der Wal G, Deliens L. Trends in acceptance of euthanasia among the general public in 12 European countries (1981-1999). Eur J Public Health 2006;16(6):663-9.

[135] CIS. Perfiles actitudinales en la sociedad española. Estudio 2203. Madrid: CIS; 1995.

[136] CIS. Religiosidad. Estudio 2752. Madrid: CIS; 2008.

[137] CIS. Valores y creencias de los jóvenes. Estudio 2440. Madrid: CIS; 2001.

[138] Barrio-Cantalejo IM, Toral-López I, Carmona-Rega I, et al. Preferencias de tratamiento de soporte vital en condiciones críticas de salud. Enferm Clin 2008;18(6):289-95.

[139] Miccinesi G, Rietjens JAC, Deliens L, et al. Continuous deep sedation: physicians' experiences in six European countries. J Pain Symptom Manage 2006;31(2):122-9.

[140] Palomar Gallardo C, Merino Navarro D, González de Grado M, et al. ¿Qué entienden los cuidadores principales de pacientes oncológicos en domicilio sobre 'muerte digna'? In: Primeras Jornadas Nacionales de la Sociedad Científica Española de Licenciados en Enfermería. Universidad de Alicante; 2001. p. 37-41 http://www.scele.enfe.ua.es/web_scele/1_jornad.htm.

[141] Del Nogal Saez F. Opiates at the end of life in an emergency department in Spain: euthanasia or good clinical practice? Intensive Care Med 2006;32(7):1086-7.

[142] Maltoni M, Pittureri C, Scarpi E, et al. Palliative sedation therapy does not hasten death: results from a prospective multicenter study. Ann Oncol 2009;20:1163-9.

[143] Fainsinger RL, Waller A, Bercovici M, et al. A multicentre international study of sedation for uncontrolled symptoms in terminally ill patients. Palliat Med 2000;14(4):257-65.

[144] Gonçalves JF, Alvarenga M, Silva A. The last forty-eight hours of life in a Portuguese palliative care unit: does it differ from elsewhere? J Palliat Med 2003;6(6):895-900.

[145] Busquet Durán X, Pujol Sabanés T. Los estudiantes de enfermería ante la muerte y el morir. Med Paliativa 2001;8(3):116-9.

[146] Hernández Rojas JM, Rodríguez Peña CA. Rosa Hormiga Mdl. Estudio descriptivo/comparativo entre profesionales sanitarios y no sanitarios sobre la ansiedad ante la muerte. Trabajo Social y Salud 2002;42:119-49.

[147] Raja Hernández R, Alba Sánchez I, Lupiani Giménez M, Gala León FJ, Guillén Gestoso C. Influencia de las creencias religiosas en las actitudes del personal de enfermería ante la muerte. Enfermería Científica 2003;(260-261):549-55.

[148] Santisteban Etxeburu I, Mier O. Estudio descriptivo de la ansiedad ante la muerte y factores estresantes en los distintos profesionales de una Unidad de Cuidados Paliativos. Med Paliativa 2006;13(1): $18-24$.

[149] Bayés R, Limonero JT, Buendía B, Burón E, Enríquez N. Evaluación de la ansiedad ante la muerte. Med Paliativa 1999;6(4):140-3.

[150] Limonero JT. Ansiedad ante la muerte. Ansiedad y Estres 1997;3(1):37-48.
[151] Moreno RP, Solana EID, Rico MA, Fernández LML. Death anxiety in institutionalized and non-institutionalized elderly people in Spain. Omega 2008;58(1):61-76.

[152] Toscani F, Borreani C, Boeri P, et al. Life at the end of life: beliefs about individual life after death and "good death" models-a qualitative study. Health Qual Life Outcomes 2003;1:65.

[153] Barrio Linares Md, Jimeno San Martín L, López Alfaro P, Ezenarro Muruamendiaraz A, Margall Coscojuela MA, Asiain Erro MC. Cuidados del paciente al final de la vida: ayudas y obstáculos que perciben las enfermeras de cuidados intensivos. Enferm Intensiva 2007;18(1):3-14.

[154] Gómez Doblas JJ, Narbona Carrión G, López Madroñero T, Rubio Olmo A, Salazar Agullo JA, Vicioso Salazar R. Identificación de variables con una técnica de consenso ( $1 \stackrel{a}{a}$ fase diseño de una encuesta de actitudes ante el paciente terminal). Aten Primaria 1993;12(8): 523.

[155] Pérez-Cárceles MD, Esteban MA, Osuna E, Luna A. Medical personnel and death. Med Law 1999;18(4):497-504.

[156] Rojas Alcántara P, Campos Aranda M, Armero Barranco D, et al. Health science students' attitude to dying. Med Law 2003;22: 301-10.

[157] Clavé Arruabarrena E, Casado Da Rocha A, Altolaguirre C. Sufrimiento insoportable y voluntad de vivir: primeros resultados de un estuido en Gipuzkoa. Med Paliativa 2006;13(4):197-206.

[158] Beccaro M, Caraceni A, Costantini M. End-of-Life Care in Italian Hospitals: Quality of and satisfaction with care from the caregivers' point of view-results from the Italian Survey of the Dying of Cancer. J Pain Symptom Manage 2010;39(6):1003-15.

[159] Costantini M, Ripamonti C, Beccaro M, et al. Prevalence, distress, management, and relief of pain during the last 3 months of cancer patients' life. Results of an Italian mortality follow-back survey. Ann Oncol 2009;20(4):729-35.

[160] Costantini M, Viterbori P, Flego G. Prevalence of pain in Italian hospitals: results of a regional cross-sectional survey. J Pain Symptom Manage 2002;23(3):221-30.

[161] Ripamonti C, Zecca E, Brunelli C, et al. Pain experienced by patients hospitalized at the National Cancer Institute of Milan: Research project "Towards a Pain-Free Hospital". Tumori 2000;86(5):412-8.

[162] Toscani F, Di GP, Brunelli C, Miccinesi G, Laquintana D. How people die in hospital general wards: a descriptive study. J Pain Symptom Manage 2005;30(1):33-40.

[163] Trentin L, Visentin M, de Marco R, Zanolin E. Prevalence of pain in a public hospital: correlation between patients and caregivers. J Headache Pain 2001;2(2):73-8.

[164] Cherny NI, Baselga J, De Conno F, Radbruch L. Formulary availability and regulatory barriers to accessibility of opioids for cancer pain in Europe: a report from the ESMO/EAPC Opioid Policy Initiative. Ann Oncol 2010;21:615-26.

[165] Bilsen J, Norup M, Deliens L, et al. Drugs used to alleviate symptoms with life shortening as a possible side effect: end-of-life care in six European countries. J Pain Symptom Manage 2006;31(2):111-21.

[166] Zenz M, Willweber-Strumph A. Opiophobia and cancer pain in Europe. Lancet 1993;341:1075.

[167] Valderrama MJ.Repitiendo para no repetir. IX. Conferencia Nacional de Antropología. Barcelona: ICA, FAAEE; 2002.

[168] Valderrama MJ. Repitiendo para no repetir, II. Atención a personas en fin de vida desde la Atención Primaria. In: Medical anthropology at home. 3. Medical anthropology, welfare state and political engagement. 2003.

[169] Valderrama MJ. Al final de la vida... Historias y narrativas de profesionales de cuidados paliativos. Barcelona: Editorial Icaria; 2008.

[170] Apolone G, Corli O, Greco MT, Zagonel V. Factors influencing the decision to take or reject opioids for cancer pain: are we on target? Ann Oncol 2008;19:1021-2.

[171] Mercadante S, Salvaggio L. Cancer pain knowledge in Southern Italy: data from a postgraduate refresher course. J Pain Symptom Manage 1996;11(2):108-15. 
[172] Porzio G, Aielli F, Narducci F, et al. Knowledge and attitudes of Italian medical oncology residents toward the approach and treatment of pain. J Pain Symptom Manage 2003;26(1):590-2.

[173] Visentin M, Trentin L, de Marco R, Zanolin E. Knowledge and attitudes of Italian medical staff towards the approach and treatment of patients in pain. J Pain Symptom Manage 2001;22(5):925-30.

[174] McCaffery M, Ferrell BR. Nurses' knowledge about cancer pain: A survey of five countries. J Pain Symptom Manage 1995;10(5):356-69.

[175] Rojas Alcántara P, Torralba Madrid MJ, Muñoz Pérez G, Alcaraz Escribano ML, Alarcón Nicolás MD, Campos Aranda M. Alumnos de enfermería y cuidados paliativos. Enfermería Científica 1996;166-167:30-4.

[176] Busquet Durán X, Porta Serra M, Jariod M, Busquet Mas C, Sánchez Blanco AM, Duocastella Bastardes P. La atención domiciliaria al enfermo de cáncer terminal: valoración y propuestas de médicos y enfermeras. Aten Primaria 1994;13(6):291-9.

[177] Esteva Cantó M, Llobera Cánaves J, Miralles Xamena J, Bauzá Amengual M. Management of terminal cancer patients: attitudes and training needs of primary health care doctors and nurses. Support Care Cancer 2000;8(6):464-71.

[178] Frías Osuna A, Prieto Rodríguez MA, Heierle Valero C, Gil García E, Aceijas Hernández C. Actitudes, percepciones y satisfacción de las enfermeras andaluzas con la atención domiciliaria. Enferm Clin 2004;14(6):297-306

[179] Uceda ME, Rodriguez JN, Mora JI. Estudio piloto sobre aspectos familiares y sociales percibidos por cuidadores principales de pacientes oncológicos en cuidados paliativos domiciliarios. Med Paliativa 2007;14(2):69-74.

[180] Costantini M, Beccaro M, Higginson IJ. Cancer trajectories at the end of life: is there an effect of age and gender? BMC Cancer 2008;8:127.

[181] Rodriguez G, De Leo C, Girtler N, Vitali P, Grossi E, Nobili F. Psychological and social aspects in management of Alzheimer's patients: an inquiry among caregivers. Neurol Sci 2003;24(5):329-35.

[182] Rossi Ferrario S, Cardillo V, Vicario F, Balzarini E, Zotti AM. Advanced care at home: caregiving and bereavement. Palliat Med 2004;18(2):129-36.

[183] Rossi PG, Beccaro M, Miccinesi G, et al. Dying of cancer in Italy: impact on family and caregiver. The Italian Survey of Dying of Cancer. J Epidemiol Commun Health 2007;61(6):547-54.

[184] Blanco Toro L, Librada Flores S, Rocafort Gil J, Cabo Domínguez R, Galea Marín T, Alonso Prado ME. Perfil del cuidador principal del enfermo en situación terminal y análisis del riesgo de desarrollar duelo patológico. Med Paliativa 2007;14(3):164-8.

[185] Molina Linde JM, Romero Cotelo J, Romero Rodríguez R, Rodríguez Sañudo RM, Gálvez Mateos R. Alteraciones emocionales en el cuidador del enfermo oncológico terminal. Med Paliativa 2005: 83-7.

[186] Molina Linde JM, Romero Cotelo J, Romero Rodríguez Y, Rodríguez Sañudo RM, Gálvez Mateos R. Encuesta de satisfacción a cuidadores en una Unidad de Cuidados Paliativos. Med Paliativa 2006;13(1):11-7.

[187] Gil García E, Escudero Carretero M, Prieto Rodríguez MA, Frías Osuna A. Vivencias, expectativas y demandas de cuidadoras informales de pacientes en procesos de enfermedad de larga duración. Enferm Clin 2005;15(4):220-6.

[188] Morasso G, Costantini M, Di Leo S, et al. End-of-life care in Italy: personal experience of family caregivers. A content analysis of open questions from the Italian Survey of the Dying of Cancer (ISDOC). Psychooncology 2008;17(11):1073-80.

[189] Fonseca A, Mira H, Gato L. Dar vida aos dias. Uma conquista da família. ONCONEWS 2007;1(3):17

[190] Pinto C, Santos L. Prestador de cuidados: Quais são as suas necessidades? ONCONEWS 2009;3(2):16.

[191] Rossi Ferrario S, Zotti AM, Ippoliti M, Zotti P. Caregivingrelated needs analysis: a proposed model reflecting current research and socio-political developments. Health Soc Care Commun 2003;11(2):103-10.
[192] Palomar Gallardo C, Merino Navarro D, Palanco González I, Pérez Cambriles JM. El apoyo socio-sanitario prestado a los pacientes terminales en domicilio y grado de satisfacción de los mismos. Medicina Paliativa 2002;9(1):3-5.

[193] Bacalhau MR, Fernandes ML, Feio M, et al. Developmental perspective of feminine caregiving - strategies and constraints. Psychooncology 2010;19:S156 [Conference: IPOS 12th world congress of psycho-oncology Quebec city, QC Canada. Conference start 20100525; conference end: 20100529. Conference Publication: (var.pagings)]

[194] Astudillo W, Casado Da Rocha A, Mendinueta C. Alivio de las situaciones difíciles y de sufrimiento en la terminalidad. San Sebastián: Sociedad Vasca de Cuidados Paliativos; 2005.

[195] Ferrer Hernández ME. Legalización de la eutanasia como opción a una muerte digna: consulta de expertos a traveés de la técnica Delphi. Cultura de los Cuidados 2002;6(11):87-95.

[196] Barello S, Saita E, Lamiani G, Graffigna G, Vegni E, Moja EA. Fatigue in patients with advanced cancer and social support: an explorative research. Psychooncology 2010;19:S257 [Conference: IPOS 12th world congress of psycho-oncology Quebec City, QC Canada. Conference Start: 20100525; conference end: 20100529. Conference Publication: (var.pagings)].

[197] Filiberti A, Ripamonti C, Totis A, et al. Characteristics of terminal cancer patients who committed suicide during a home palliative care program. J Pain Symptom Manage 2001;22(1):544-53.

[198] Barbosa M, Lopes R, Santos J, Morais M. O familiar do doente oncológico hospitalizado: percepção da informação recebida dos profissionais. ONCONEWS 2007;1(2):9.

[199] Gonçalves Pereira MA. Má noticia em saúde: um olhar sobre as representações dos profissionais de saúde e cidadãos. Texto \& Contexto Enfermagem 2005;14(1):33-7.

[200] Mosconi P, Aloé F, Bruno G, et al. The patient's point of view. Results of the Working Group on Socio-Psychological Implications of Follow-up. Ann Oncol 1995;6(Suppl. 2):65-8.

[201] Salinas Martín A, Asensio Fraile A, Armas J, Benítez del Rosario MA. Cuidados paliativos en atención primaria: opinión de los profesionales. Aten Primaria 1999;23(4):187-91.

[202] García García JA, Landa Petralanda V, Trigueros Manzano MC, Calvo Ahedo P, Gaminde Inda I. El duelo por la pérdida del cónyuge, un estudio mediante grupos de discusión en atención primaria. Aten Primaria 1993;12(8):537.

[203] Casanueva-Mateos L, Ruiz-López P, Ignacio Sánchez-Díaz J, et al. Cuidados al final de la vida en la unidad de cuidados intensivos pediátricos. Empleo de técnicas de investigación cualitativa para el análisis del afrontamiento de la muerte y situaciones críticas. Rev Calid Asist 2007:36-43.

[204] García-Caro MP, Cruz-Quintana F, Río-Valle JS, et al. Influencia de las emociones en el juicio clínico de los profesionales de la salud a propósito del diagnóstico de enfermedad terminal. Int J Clin Health Psychol 2010;10(1):57-73.

[205] Barrio Cantalejo IM, Barreiro Bello JM, Pascau González-Garzón MJ, Simón Lorda P, Güemez Abad MP, Rimared G. La perspectiva de las personas mayores sobre el testamento vital. Index de enfermería 2006:35-9.

[206] Montoya Juárez R. Aquellos que nos verán morir. Significado y respuesta de los profesionales sanitarios de una residencia de ancianos ante la muerte y los moribundos. Index de enfermería 2006: 25-9.

[207] Socorro LL, Tolson D, Fleming V. Exploring Spanish emergency nurses' lived experience of the care provided for suddenly bereaved families. J Adv Nurs 2001;35(4):562-70.

[208] García Hernández AM, Darias Curvo S. Conceptos del anciano sobre la muerte. Gerokomos 2003;14(2):74-9.

[209] Prieto Rodríguez MA, Gil García E, Heierle Valero C, Frías Osuna A. La perspectiva de las cuidadoras informales sobre la atención domiciliaria. Un estudio cualitativo con ayuda de un programa informático. Rev Esp Salud Publica 2002;76(5):613-25. 
[210] Larkin PJ, Schotsmans P. Transitions towards end of life in palliative care: an exploration of its meaning for advanced cancer patients in Europe. J Palliat Care 2007;23(2):69-79.

[211] Goopy S. that the social order prevails: death, ritual and the 'Roman' nurse. Nursing Inquiry 2006;13(2):110-7.

[212] Mol A. The logic of care. Health and the problem of patient choice. New York: Routledge; 2008.

[213] Fassin D. Culturalism as ideology. In: Obermeyer CM, editor. Cultural perspectives on reproductive health. Oxford: Oxford University Press; 2001. p. $300-18$.

\section{Biographies}

Arantza Meñaca, Ph.D., is a medical anthropologist and post-doctoral fellow in Barcelona Centre for International
Health Research (Barcelona). She has done research in the therapeutic itineraries and relations with the health system of different population groups - migrants, pregnant women, people living with HIV - in Spain, Ecuador, Ghana, Malawi and Mozambique.

Marjolein Gysels, anthropologist, is an Associate Research Professor at the Barcelona Centre for International Health Research (CRESIB) at the University of Barcelona, and Senior Research Fellow at the Department of Palliative Care, Policy and Rehabilitation at King's College London. Her main fields of scientific interest are: palliative care, culture, qualitative research, experience of illness and symptoms, care, ethics. 